Marc Licker MD,

Alexandre Schweizer MD,

Laurent Höhn MD,

Cedric Farinelli $\mathrm{PhD}$, *

Denis R. Morel MD*

\section{Cardiovascular responses to anesthetic induction in patients chronically treated with angiotensin- converting enzyme inhibitors}

Purpose: To investigate the effects of chronic ACE inhibition on cardiac neural function following induction of general anesthesia in patients with underlying coronary artery disease.

Method: In a prospective case-control study, heart rate variability (HRV) and baroreflex control were compared preoperatively and 30 min after anesthesia induction in patients receiving, or not, ACEI ( $n=16$, control group and $\mathrm{n}=16$, ACEl group). All patients had normal cardiac function and anesthesia consisted of a fixed dose regimen of fentanyl and midazolam. Anesthesia-related hypotension was defined by systolic blood pressure $<90 \mathrm{mmHg}$. Spectral density of HRV was calculated for low frequency and high frequency bands (LF, from 0.05 to $0.15 \mathrm{~Hz}$ and HF, from $>0.15$ to $0.6 \mathrm{~Hz}$ ). Baroreflex sensitivity was estimated after blood pressure changes induced by injections of phenylephrine (PHE) and nitroglycerin (NTG).

Results: The HRV parameters and baroreflex sensitivity were not different between groups, during the awake and anesthesia periods. Anesthesia produced similar reduction in total HRV in the Control and ACEl groups (-93 $\pm 28 \%$ vs $-89 \pm 32 \%$, ) and in baroreflex sensitivity during NTG (-64 $\pm 21 \%$ vs $-54 \pm 17 \%)$ or PHE tests $(-74 \pm 25 \%$ vs $-72 \pm 22 \%$ ). Anesthesia-related hypotension occurred in nine patients in the ACEl group (vs two controls). Although the hypertensive response to phenylephrine was greater after anesthesia in both groups, the sensitivity to phenylephrine was attenuated in those patients experiencing hypotension in the ACEl group.

Conclusions: Chronic preoperative treatment with ACEls does not influence cardiac autonomic regulation and anesthetic-induced hypotensive episodes are mainly attributed to decreased -adrenergic vasoconstrictive response.

Objectif : Rechercher les effets d'une inhibition chronique de l'ECA sur la fonction neurale cardiaque à la suite de l'induction d'une anesthésie générale chez des patients qui présentent une cardiopathie ischémique sous-jacente.

Méthode : Lors d'une étude prospective cas-témoins, la variabilité de la fréquence cardiaque (VFC) et le contrôle baroréflexe ont été comparés avant l'opération et 30 min après l'induction de l'anesthésie chez des patients qui reçoivent, ou non, un IECA (groupe témoin : $n=16$, groupe IECA $: n=16$ ). Tous les patients présentaient une fonction cardiaque normale et l'anesthésie comprenait un schéma posologique fixe de fentanyl et de midazolam. On a défini l'hypotension reliée à l'anesthésie comme la tension artérielle systolique $<90 \mathrm{mmHg}$. La densité spectrale de la VFC a été calculée pour des bandes de basses et de hautes fréquences (BF, de 0,05 à $0,15 \mathrm{~Hz}$ et HF, de > 0,15 à $0,6 \mathrm{~Hz}$ ). La sensibilité baroréflexe a été évaluée après les changements de pression sanguine induits par les injections de phényléphrine (PHE) et de nitroglycérine (NTG).

Résultats : Les paramètres de la VFC et la sensibilité baroréflexe n'ont pas présenté de différence intergroupe pendant les périodes d'éveil et d'anesthésie. L'anesthésie a produit une réduction similaire de la VFC totale dans les groupes témoin et IECA $(-93 \pm 28 \%$ vs $-89 \pm 32 \%$,), et de la sensibilité baroréflexe pendant les tests avec la NTG (-64 $\pm 21 \%$ vs $-54 \pm 17 \%)$ ou la PHE (-74 $\pm 25 \%$ vs $-72 \pm 22 \%)$. L'hypotension reliée à l'anesthésie est survenue chez neuf patients du groupe IECA (vs deux témoins). Bien que la réponse hypertensive à la phényléphrine ait été plus grande après l'anesthésie dans les deux groupes, la sensibilité à la phényléphrine a été atténuée chez les patients qui ont présenté de l'hypotension dans le groupe IECA.

Conclusion : Le traitement préopératoire prolongé avec l'IECA n'influence pas la régulation autonomique cardiaque et l'hypotension induite par l'anesthésique est principalement causée par la diminution de la réponse vasoconstrictive $\alpha$-adrénergique.

From the Divisions of Anesthesiology and Anesthesiological Investigations, ${ }^{*}$ Hôpital Cantonal Universitaire, Switzerland. Address correspondence to: Dr. Marc Licker, Division d'Anesthésiologie, Hôpital Cantonal Universitaire, CH-1211 Geneve 14, Switzerland. Phone: 41-22-3827402; Fax: 41-22-3727690; E-Mail: marc-joseph.licker@hcuge.ch Accepted for publication February 2, 2000. 
$\mathrm{L}$

ONG term inhibition of angiotensin-converting enzyme has been demonstrated to prolong survival and improve quality of life in several cardiovascular and renal diseases. ${ }^{1-3}$ As a result, an increasing number of patients undergoing coronary artery bypass or valve surgery are now chronically treated with angiotensin-converting enzyme inhibitors (ACEIs). Some of these patients are prone to develop hypotensive episodes during anesthesia induction and weaning from cardiopulmonary bypass. ${ }^{4,5}$ Adrenergic receptor hyporesponsiveness and regression of cardiovascular hypertrophy are thought to be implicated in such impaired hemodynamic control. ${ }^{6}$ Although ACEIs are capable of reducing sympathetic drive and augmenting vagal tone in awake subjects, ${ }^{7}$ it is unknown whether such alterations in baroreflex function and sympathovagal balance also occur during anesthesia which could be incriminated in hypotensive events.

In a variety of pathophysiological conditions, measurements of heart rate variability (HRV) and heart rate baroreflex response have emerged as valuable tools to characterize the changes in cardiac neural control. ${ }^{8-11}$ Baroreflex function is influenced by vagal/sympathetic neural outflows, baroreceptor sensitivity and cardiovascular end-organ responsiveness. Spectral analysis breaks down a series of consecutive heart beats into its constituent frequency components and quantifies the power of these components. Three frequency bands have been described: very low frequency (VLF, 0.0004$0.05 \mathrm{~Hz}$ ), low frequency (LF, 0.05-0.15 Hz) and high frequency $(\mathrm{HF}, 0.15-0.5 \mathrm{~Hz})$. VLF bands are related to peripheral vasomotor activity and several cardiorespiratory phenomena; these are often neglected in many investigations. Classically, HF bands are associated with vagal activity occurring in phase with ventilation whereas the LF component is related to a resonance phenomenon within the baroreflex loop that reflects both the sympathetic and vagal components; finally, the $\mathrm{LF} / \mathrm{HF}$ ratio is commonly used as an index of the sympathetic tone.

In this case-control study, we compared cardiac neural regulation in two groups of patients receiving or not, chronic preoperative therapy with ACEIs and undergoing coronary artery bypass surgery under midazolam-fentanyl anesthesia. Cardiac autonomic nervous system function was assessed by HRV analysis and by calculating the slope of the baroreflex; vascular end-organ responsiveness was also estimated by the pressure changes induced by bolus administration of phenylephrine (PHE) and nitroglycerin (NTG).
Methods

Patient selection and management

After obtaining institutional Ethics Committee approval and informed consent, 32 patients scheduled for elective coronary artery bypass graft surgery were investigated in an open, prospective, case-control study. All patients had moderate to well-preserved left ventricular function (ejection fraction $\geq 40 \%$ ), and those with diabetes, arrhythmias, conduction abnormalities, recent myocardial infarction ( $<30 \mathrm{dy})$ and impaired renal function (creatinine clearance $<60$ $\mathrm{ml} \cdot \mathrm{min}^{-1}$ ) were excluded from the study. The usual cardiac medications, except diuretics, were administered up to the morning of surgery.

After overnight fasting, each patient received 0.15 $\mathrm{mg} \cdot \mathrm{kg}^{-1}$ morphine $i m$ as premedication one hour before operation. On arrival in the induction room, a five-lead ECG monitor was used to monitor heart rate (HR), rhythm and ST segment changes (Datex AS3, Helsinki, Finland). Arterial radial, jugular venous and pulmonary artery catheters were inserted under local anesthesia for continuous monitoring of mean arterial, central venous and pulmonary arterial pressures (MAP, CVP and PAP) as well as intermittent cardiac output (CO) measurements. General anesthesia was conducted by an experienced anesthesiologist not involved in the study: for induction, $15 \mu \mathrm{g} \cdot \mathrm{kg}^{-1}$ fentanyl and $40 \mu \mathrm{g} \cdot \mathrm{kg}^{-1}$ midazolam were administered intravenously $(i v)$ over three to five minutes and then $0.15 \mathrm{mg} \cdot \mathrm{kg}^{-1}$ pancuronium was given to facilitate tracheal intubation and pulmonary ventilation. Thereafter, anesthesia was maintained with continuous infusions of $100 \mu \mathrm{g} \cdot \mathrm{kg}^{-1} \cdot \mathrm{hr}^{-1}$ midazolam and 5 $\mu \mathrm{g} \cdot \mathrm{kg}^{-1} \cdot \mathrm{hr}^{-1}$ fentanyl. During mechanical ventilation, a fixed-respiratory rate of $16 \cdot \mathrm{min}^{-1}$ was used and tidal volume was adjusted to keep normocapnia (5-5.5 kPa) and normoxia (oxygen saturation $\geq 98 \%$ ).

All patients received $10 \mathrm{ml} \cdot \mathrm{kg}^{-1}$ Lactate-Ringer solution $i v$ before anesthesia induction and 5 $\mathrm{ml} \cdot \mathrm{kg}^{-1} \cdot \mathrm{hr}^{-1}$ for the remaining part of the study.

\section{Study design}

Based on medical history, two groups of consecutive patients were considered over an eight month period: those treated with ACEIs for at least three months (ACEI group) and case-controls matched for age and type of surgery who did not receive ACEIs (control group). The sample size calculation was based on HRV data and baroreflex slope determined in a previous study. ${ }^{12}$ The calculations indicated that, to show a difference greater or equal to 1.2 standard deviation with a power of $90 \%$ and a significance of level of $5 \%$, 16 patients should be evaluated in each group. 
TABLE I Preoperative and surgical data

\begin{tabular}{llll}
\hline & Control group & $\begin{array}{l}\text { ACEI group } \\
\text { no hypotension } \\
n=7\end{array}$ & $\begin{array}{l}\text { with bypotension } \\
n=9\end{array}$ \\
\hline $\begin{array}{l}\text { Demographic data } \\
\text { Age (yr) }\end{array}$ & $59 \pm 6$ & $58 \pm 5$ & $62 \pm 8$ \\
Weight (kg) & $77 \pm 9$ & $76 \pm 10$ & $74 \pm 11$ \\
Height (cm) & $172 \pm 4$ & $177 \pm 6$ & $174 \pm 7$ \\
Sex (M/F) & $13 / 3$ & $5 / 2$ & $7 / 2$ \\
Medical history & & & 3 \\
Previous myocardial & 4 & 2 & 8 \\
infarct & 11 & 5 & $55 \pm 12$ \\
Arterial hypertension & $57 \pm 11$ & $52 \pm 11$ & 1 \\
LVEF (\%) & 11 & 2 & 2 \\
B-blockers & 6 & 1 & 6 \\
Calcium-channel blockers & 13 & 5 & \\
Nitrates & & & \\
\hline
\end{tabular}

Data are mean \pm SD or absolute numbers; LVEF, left ventricular ejection fraction

\section{Measurements and calculations}

Data were collected at two time periods during stable hemodynamic and respiratory conditions: 1) before anesthesia induction in awake patients (awake) and 2) $20 \mathrm{~min}$ after anesthesia induction, before prepping and surgical incision (anesthesia), respiratory rate, end-expiratory carbon dioxide $\left(\mathrm{P}_{\mathrm{ET}} \mathrm{CO}_{2}\right)$, systemic hemodynamic variables (MAP, $\mathrm{HR}, \mathrm{CVP})$ were averaged over a period of five to eight minutes while the ECG signals were recorded and stored for off-line HRV analysis; thereafter, $\mathrm{CO}$ was measured in triplicate by the thermodilution technique and baroreflex testing was performed using vasoactive drugs (PHE, NTG).

Following anesthesia induction, any hypotensive event defined by systolic arterial pressure (SAP) $<90$ $\mathrm{mmHg}$ was treated with phenylephrine (PHE, $100 \mu \mathrm{g}$ bolus) and by increasing the infusion of LactateRinger solution. For each patient, the total amounts of fluids and PHE were calculated over 15 min after anesthesia induction.

The ECG signal was fed into a purpose-built $R$ wave detector to generate a series of successive RR intervals with an accuracy of $1 \mathrm{msec}$. The invasive radial artery pressure signal was simultaneously recorded and analog-to-digital converted using a 16-bit board with a temporal resolution of $1000 \mathrm{~Hz}$ and an amplitude resolution of 12 bits (Lab- view; National Instruments, Austin, TX).

The time domain analysis of HRV was assessed by calculating the standard deviation of successive $R R$ intervals (SDNN, msec). Spectral estimation of RR interval variability was obtained from stationary regions of five minute recordings containing repeated segments of more than 100 successive RR intervals with less than $2 \%$ ectopy. When present, extrasystolic beats were deleted and replaced by appropriately spaced values; missed beats were inserted by interpolation. After detrending of the signal (first degree), an autoregressive algorithm was used to obtain a spectral density estimate of RR interval variability. ${ }^{2}$ Spectral density was calculated as the area under the curve of two frequency bands: low frequency (LF, from 0.05 to $0.15 \mathrm{~Hz}$ ) and high frequency $(\mathrm{HF}$, from $>0.15$ to 0.6 $\mathrm{Hz}$ ), and was expressed in absolute units in millisecond squared. In addition, the LF/HF ratio was calculated as an index of sympathovagal balance. Transfer function analysis confirmed the absence of respiratorydependent oscillations of HR in the LF component whereas a significant relationship was found between respiration and the HF component.

To examine the baroreflex control of $\mathrm{HR}$, interbeat interval responses to vasoconstrictor-induced hypertension and vasodilator-induced hypotension were analyzed. All R-R intervals were paired with the SAP values of the preceding beat and the baroreflex sensitivity was defined as the slope obtained by regression analysis of the linear portion of the curve (excluding values when $\mathrm{R}<0.9$ ) and expressed as the change in RR interval in milliseconds per millimeters mercury of change in SAP. Blood pressure was raised and lowered by random alternating bolus injections of PHE (50 $\mu \mathrm{g}$, with $50 \mu \mathrm{g}$ increments) and NTG (50 $\mu \mathrm{g}$, with 50 $\mu \mathrm{g}$ increments) until SAP increased or decreased by at least $25 \mathrm{mmHg}$, respectively, or until a maximum of $200 \mu \mathrm{g}$ had been given. SAP and HR were allowed to return to baseline levels between each type of vasoac- 
TABLE II Hemodynamic and respiratory data

\begin{tabular}{|c|c|c|}
\hline & Awake & $\begin{array}{l}\text { 20-min } \\
\text { anesthesia }\end{array}$ \\
\hline \multicolumn{3}{|c|}{ Heart rate (beats. $\min ^{-1}$ ) } \\
\hline Control & $63 \pm 5$ & $55 \pm 4^{*}$ \\
\hline ACEI & $65 \pm 7$ & $57 \pm 5^{*}$ \\
\hline \multicolumn{3}{|c|}{ Mean arterial pressure $(\mathrm{mmHg})$} \\
\hline Control & $102 \pm 7$ & $84 \pm 11^{*}$ \\
\hline ACEI & $103 \pm 11$ & $87 \pm 12^{*}$ \\
\hline \multicolumn{3}{|c|}{ Cardiac output $\left(\mathrm{L} \cdot \mathrm{min}^{-1}\right)$} \\
\hline Control & $4.5 \pm 1.2$ & $3.8 \pm 0.8^{*}$ \\
\hline ACEI & $4.4 \pm 1.1$ & $3.6 \pm 0.9^{*}$ \\
\hline \multicolumn{3}{|c|}{ Central venous pressure $\left(\mathrm{cmH}_{2} \mathrm{O}\right)$} \\
\hline Control & $3 \pm 2$ & $7 \pm 3^{*}$ \\
\hline ACEI & $4 \pm 3$ & $8 \pm 4^{*}$ \\
\hline \multicolumn{3}{|c|}{ End-tidal $\mathrm{CO}_{2}(\mathrm{kPa})$} \\
\hline Control & $5.1 \pm 0.5$ & $4.6 \pm 0.2^{*}$ \\
\hline ACEI & $5.0 \pm 0.4$ & $4.5 \pm 0.2$ * \\
\hline \multicolumn{3}{|c|}{ Respiratory rate $\left(\right.$ breath $\cdot \mathrm{min}^{-1}$ ) } \\
\hline Control & $14 \pm 2$ & 16 \\
\hline ACEI & $13 \pm 1$ & 16 \\
\hline
\end{tabular}

Data are expressed as mean \pm SD or median (range).

${ }^{*} P<0.05$, compared with awake values; no difference between the two groups.

tive drug injections. The magnitude of increase, and decrease, in SAP after PHE and NTG was expressed in millimeters mercury per $100 \mu \mathrm{g}$ drug.

\section{Data analyses}

Data were checked for normal distribution using the Kolmogorov-Smirnov test. Normal data are presented as means $\pm \mathrm{SD}$; otherwise data are shown as medians (range). The spectral parameters and baroreflex slopes were analyzed after logarithmic transformation to improve skewness and kurtosis. Data were analyzed using a two-way ANOVA with one repeated variable as well as Student's $t$ test or Fisher's exact test. The association between baroreflex, time-domain indices and HRV also examined using Spearman's rank correlation coefficient. Multiple linear regression analysis with stepwise selection of independent variables was performed to identify relationships among cardiac autonomic tests and hemodynamic changes during anesthesia induction. For all analyses, a $P$ value of 0.05 was used to determine significance.

Results

The two groups did not differ with regard to demographic data and medical history (Table I); however, B-blockers were more often prescribed in the Control group (11 patients vs three in the ACEI group, $P<$ $0.05)$. In the ACEI group, patients were treated for a
TABLE III Heart rate variability (HRV) in time and frequency domains

\begin{tabular}{|c|c|c|c|}
\hline & & preoperative & anesthesia \\
\hline \multirow[t]{2}{*}{$\mathrm{R}-\mathrm{R}$ interval (msec) } & control & $902 \pm 129$ & $994 \pm 172^{*}$ \\
\hline & ACEI & $918 \pm 90$ & $943 \pm 107^{\star}$ \\
\hline sd of RR (msec) & control & $35 \pm 13$ & $11 \pm 4^{*}$ \\
\hline Total HRV $\left(\operatorname{msec}^{2} \cdot \mathrm{Hz}^{-1}\right)$ & $\begin{array}{l}\text { ACEI } \\
\text { control }\end{array}$ & $\begin{array}{l}29 \pm 15 \\
790 \pm 545\end{array}$ & $\begin{array}{l}10 \pm 3^{*} \\
66 \pm 39^{*}\end{array}$ \\
\hline \multicolumn{4}{|c|}{ HighFrequency $\left(\mathrm{msec}^{2} \cdot \mathrm{Hz}^{-1}\right)$} \\
\hline & control & $223 \pm 188$ & $4.2 \pm 3.1^{*}$ \\
\hline & ACEI & $211 \pm 202$ & $4.9 \pm 3.0^{*}$ \\
\hline \multicolumn{4}{|c|}{ Low Frequency (\% total HRV) } \\
\hline & control & $32 \pm 14$ & $8 \pm 3^{*}$ \\
\hline & ACEI & $29 \pm 8$ & $9 \pm 3^{*}$ \\
\hline \multicolumn{4}{|c|}{ Low Frequency $\left(\mathrm{msec}^{2} \cdot \mathrm{Hz}^{-1}\right)$} \\
\hline & control & $178 \pm 113$ & $38 \pm 26^{*}$ \\
\hline & ACEI & $294 \pm 289$ & $36 \pm 22^{*}$ \\
\hline \multicolumn{4}{|c|}{ High Frequency (\% total HRV) } \\
\hline & control & $23 \pm 8$ & $72 \pm 15^{*}$ \\
\hline & ACEI & $39 \pm 13$ & $65 \pm 13^{*}$ \\
\hline \multicolumn{4}{|l|}{ Low / High Frequency } \\
\hline & control & $1.21 \pm 0.61$ & $0.15 \pm 0.08^{*}$ \\
\hline & ACEI & $0.92 \pm 0.42$ & $0.14 \pm 0.07^{*}$ \\
\hline
\end{tabular}

${ }^{*} P<0.05$, compared with preoperative period; no difference between the two groups

TABLE IV Baroreflex slope

\begin{tabular}{clll}
\hline & & preoperative & anesthesia \\
\hline nitroglycerin test & control & $3.4 \pm 1.2$ & $1.2 \pm 0.6^{*}$ \\
$\left(\mathrm{msec} \cdot \mathrm{mmHg}^{-1}\right)$ & ACEI & $3.9 \pm 1.8$ & $1.8 \pm 0.9^{*}$ \\
phenylephrine test & control & $8.2 \pm 3.1$ & $2.1 \pm 1.2^{*}$ \\
$\left(\mathrm{msec}_{\mathrm{mmHg}} \mathrm{mmH}^{-1}\right)$ & ACEI & $7.1 \pm 4.2$ & $1.9 \pm 1.1^{*}$ \\
\hline
\end{tabular}

${ }^{*} P<0.05$, compared with preoperative period; no difference between the two groups

median period of 6.5 months (range 3 to $36 \mathrm{mo}$ ) before surgery with captopril $(\mathrm{n}=3$, median daily dose of $75 \mathrm{mg}$ )), enalapril ( $\mathrm{n}=7$, median daily dose of 20 $\mathrm{mg})$, perindopril $(\mathrm{n}=3$, median daily dose of $4 \mathrm{mg}$ ) and lisinopril $(\mathrm{n}=3$, median daily dose of $10 \mathrm{mg}$ ). Hemodynamic values, respiratory rate and $\mathrm{P}_{\mathrm{ET}} \mathrm{CO}_{2}$ were similar in the two groups at each measurement periods although MAP and CO were lower and CVP was higher during anesthesia and controlled ventilation compared with baseline awake values and spontaneous respiration (Table II).

Following anesthesia induction, short-lasting hypotensive episodes $(<60 \mathrm{sec})$ occurred in nine patients in the ACEI group and in two patients in the control group $(P<0.05)$. To correct arterial hypotension, ACEI-treated patients were given a greater 


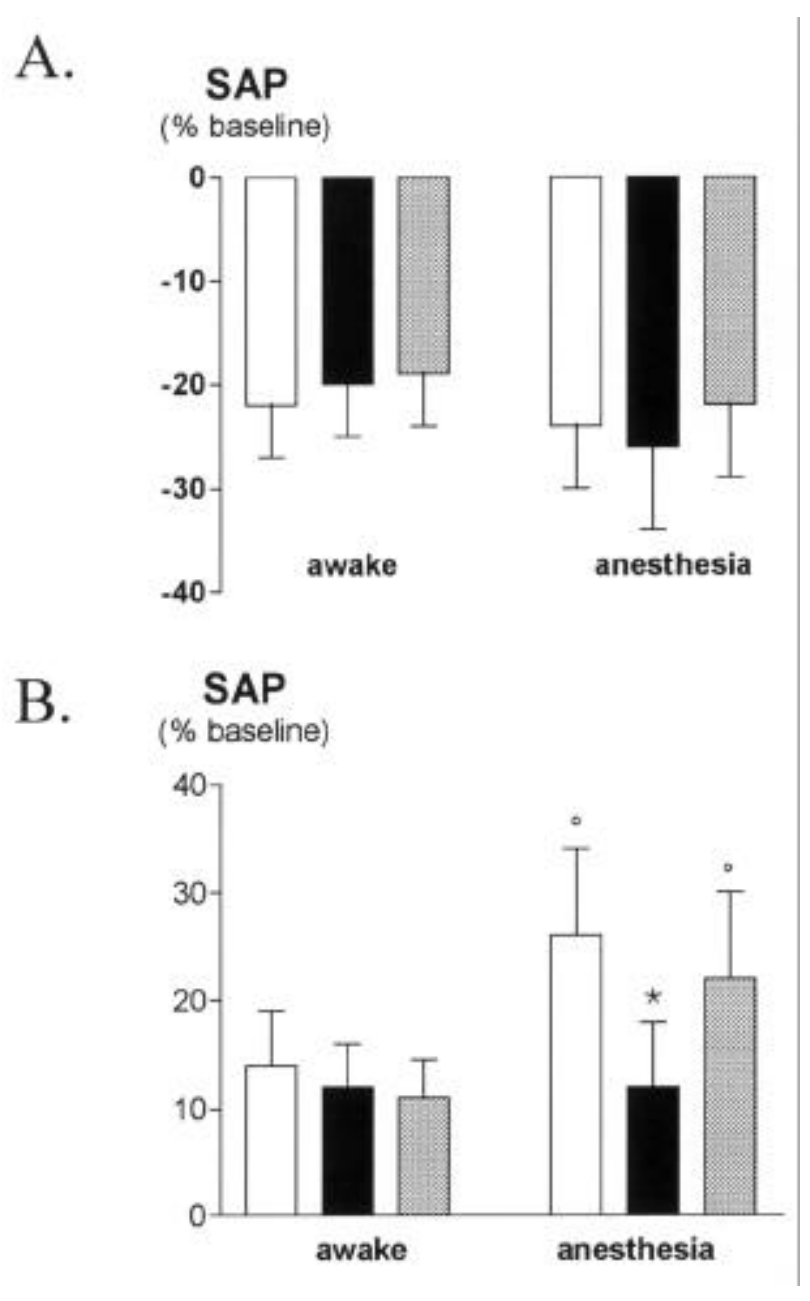

FIGURE 1A Changes in systolic arterial pressure (SAP) induced by nitroglycerine before (awake) and $20 \mathrm{~min}$ after anesthesia induction (anesthesia) in control patients $(n=16, \quad)$ and ACEItreated subgroups who had anesthesia-related hypotension $(\mathrm{n}=9, \mathbf{\square})$ or stable hemodynamics $(\mathrm{N}=7, \square)$.

FIGURE IB Changes in systolic arterial pressure (SAP) induced by phenylephrine before (awake) and $20 \mathrm{~min}$ after anesthesia induction (anesthesia) in control patients $(n=16$, ) and two ACEItreated subgroups who had anesthesia-related hypotension $(n=9, \boldsymbol{m})$ or stable hemodynamics $(\mathrm{N}=7, \square)$. Data are presented as mean and SD. * Indicates significant differences between the two groups and indicates differences compared with the awake period.

amount of iv fluids (500[150-1000] ml vs $150[50$ $400] \mathrm{ml}$ in the Control group, $P<0.05)$ and of phenylephrine (100[0-300] $\mu \mathrm{g}$ vs $0[0-100] \mu \mathrm{g}$ in the Control group, $P<0.05)$. Automated analysis of ST segment did not show significant changes $(\geq 1 \mathrm{mV}$ depression or $\geq 2 \mathrm{mV}$ elevation at J point $+60 \mathrm{msec}$, lasting $\geq 60 \mathrm{sec})$.
As shown in Tables III and IV, all HRV parameters and baroreflex sensitivity were not different between the two groups, during the two study periods. Following anesthesia induction, total HRV decreased by $93 \pm 28 \%$ in the Control group and by $89 \pm 32 \%$ in the ACEI group. However, there was a greater reduction in the LF $(-75 \%$ in controls and $-77 \%$ in ACEIs, $P<0.001)$ than in the HF $(-28 \%$ in controls and $-30 \%$ in ACEIs, $P<0.01)$ that resulted in a decrease in LF/HF ratio $(-85 \%$ in controls and $-74 \%$ in ACEIs, $P$ $<0.001)$ and a relative increase in normalized HF bands $(\% \mathrm{HF} /$ total HRV $+273 \pm 88 \%$ in controls and $+198 \pm 62 \%$ in ACEIs $)$.

The tachycardic and bradycardic responses to NTG and PHE were markedly blunted after anesthesia induction in the ACEI group $(-60 \pm 11 \%$ and $-64 \pm$ $15 \%$, respectively) and in the control group ( $-63 \pm 9 \%$ and $-75 \pm 10 \%$, respectively). There was no correlation between HRV parameters and baroreflex slopes.

The hypotensive response to NTG was not influenced either by anesthesia or by preoperative ACEI therapy whereas the hypertensive response to PHE was greater after anesthesia in both groups (Figures $1 \mathrm{~A}, \mathrm{~B})$. However, in the ACEI subgroup of patients experiencing hypotension $(n=9)$, the sensitivity to the pressor effects of PHE was attenuated.

In the ACEI group, cardiac autonomic tests (HRV and baroreflex sensitivity) were not different between patients with and without anesthesia-induced hypotension as well as between patients pretreated or not with $B$-blockers. Multiple linear regression analysis did not identify any relationship among the cardiac autonomic tests, NTG vasodilating test and the hemodynamic changes during anesthesia induction.

\section{Discussion}

Chronic blockade of the renin-angiotensin system does not influence cardiac autonomic regulation in awake or anesthetized patients. Following anesthesia induction, HRV parameters and baroreflex sensitivity were decreased in all patients and hypotensive events were likely related to impaired -adrenergic vasoconstrictive response in patients chronically treated with ACEIs.

\section{Limitations of the study}

This was a non-randomized study involving patients with ischemic heart disease who were well matched for preoperative medical condition, except for $\beta$-adrenergic blocking medications. Presumably, this reflected the general medical practice of prescribing either $\beta$ blockers or ACEIs, alone or associated with calcium antagonists and/or nitrates to treat arterial hyperten- 
sion. Although chronic preoperative treatment with $B$ blockers does not alter ${ }_{1}$ - vasoconstrictive response or baroreflex sensitivity in awake or anesthetized cardiac patients, ${ }^{14,15}$ it may be a risk factor for hypotension and bradyarythmias as a result of the interactive effects with anesthetics causing cardiac depression and peripheral vasodilatation. ${ }^{16}$

The study was limited to two, short, ten minute periods and several factors (e.g., external stimulation, fluid loading and the respiratory mode) were expected to alter the activity of the autonomic nervous system in both groups. First, spectral HRV analysis using autoregressive modeling requires stationary data and, therefore, allowed comparison between two stable conditions, - awake and anesthetized -, in the absence of any disturbances such as skin preparation, draping or surgical incision. Second, although the infused volume of Ringer's lactate solution was higher in the ACEI group, central venous pressure was similar in the two groups and therefore would cause similar activation of the low-pressure atrial baroreceptors. Third, converting from spontaneous breathing to a fixed mode of positive pressure ventilation enhances vagal activity and thus contributed to increase the power of HF component. ${ }^{17}$

\section{Heart rate variability and baroreflex analysis}

Variable impairment in cardiac neural regulation has been demonstrated in relation to aging, diabetes mellitus, heart failure, myocardial infarct and hypertension. ${ }^{10,18,19}$ Although autonomic function tests are unable to differentiate between the severity of cardiovascular diseases and the effects of medication, low values of either baroreflex sensitivity or HRV carry a considerable risk of cardiac complications. ${ }^{20,21}$ Interestingly, in congestive heart failure, the beneficial effects of ACEIs have been associated with reduced neurohumoral activation (e.g., lower plasma concentrations of catecholamines and atrionatriuretic factor), improved baroreflex control as well as with increased vagal tone and total $\mathrm{HR}$ oscillations. ${ }^{22}$ In the present study, patients with severe left ventricular dysfunction were excluded and the majority of patients presented with arterial hypertension. In the awake period, baroreflex sensitivity was in the same range as in previous investigations involving hypertensive subjects (2-4 $\mathrm{msec} / \mathrm{mmHg}$ for NTG test and $4-13 \mathrm{msec} / \mathrm{mmHg}$ for PHE test) whereas much lower values have been reported in patients with heart failure. ${ }^{23,24}$ In agreement with our data, several studies showed that neither ACEIs nor $B$-blockers altered HRV parameters under stress-free conditions ${ }^{25,26}$ whereas during acute stressful conditions such as myocardial ischemia, orthostasis and mental stress, both medications tended to reduce the $\mathrm{LF} / \mathrm{HF}$ ratio of $\mathrm{HRV}$ indicating reduced activation of the sympathetic nervous system. ${ }^{10}$

Regardless of preoperative cardiac medications, anesthesia with moderate doses of fentanyl and midazolam produced marked impairment of cardiac autonomic regulation as demonstrated by $>50 \%$ reduction in HR baroreflex sensitivity and in all HRV parametres with a shift towards relative HF dominance. The decrease in $\mathrm{LF} / \mathrm{HF}$ ratio, the increased relative $\mathrm{HF}$ power and the lower basal heart rates were consistent with a predominant vagal tone which could not be further activated during PHE-induced hypertension. Several studies have also described marked reduction of all components of the HRV power spectra follow ing anesthesia induction with inhaled and $i v$ anesthetics. ${ }^{27-29}$ Changes in cardiac autonomic neural output are largely depended on anesthetic depth, surgical stimulation and opiate dosage. Using a lower dose opioid-benzodiazepine regimen, Kortly et al. demonstrated that vagal activity, - but not cardiac sympathetic neural drive -, could be further increased as indicated by baroreflex mediated $\mathrm{HR}$ changes in response to $\mathrm{PHE}$ and NTG. ${ }^{30}$

\section{Anesthesia-induced bypotension}

In order to maintain hemodynamic stability during anesthesia induction, nine of 16 patients in the ACEI group (and two controls) required additional $i v$ fluids and vasoconstrictors. The release of catecholamines has been reported to be unaffected by chronic renin angiotensin blockade ${ }^{6,31}$ and, in the present study, a significant alteration in cardiac neural regulation could be ruled out. Anesthesia-induced hypotension was associated with decreased vascular-adrenergic response and it could not be predicted by any preoperative tests of the autonomic nervous system. Hemodynamic homeostasis during anesthesia appears to be altered by pharmacological blockade of the renin angiotensin system and by dose-related anesthetic-induced inhibition of the sympathetic nervous system. Indeed, most hypotensive events can be prevented either by stopping the ACEI 24-48 hr before surgery or, - instead of giving a fixed dose regimen -, by titrating and reducing the anesthetic dosage according to the hemodynamic effects. $4,6,32$

As already reported by Schwinn $e t a l .,^{3}$ the vasopressor response to PHE was greater during anesthesia than in the awake period in patients with an intact renin angiotensin system. Altogether these data suggest that anesthetic-induced relaxation of peripheral vasomotor tone unmasked the positive interaction between the vasoconstrictive effects of angiotensin II and PHE. 
According to our data and previous studies, ${ }^{34,35}$ it appears that chronic therapy with ACEIs does not influence cardiac neural autonomic control but that it may variably attenuate adrenergic vasoconstrictor response as a result of tissue and plasma depletion of angiotensin II, regression of vascular smooth muscle and enhanced release of endothelial vasodilatory factors. ${ }^{6}$ It is of interest that angiotensin II interactions with cardiac sympathetic innervation are much less pronounced than with neurons innervating vascular smooth muscle. Hence, the ability of ACEIs to attenuate sympathetically mediated responses is mainly confined to the peripheral and coronary vasculature. ${ }^{35}$ Indeed, sympathetically-induced coronary vasoconstriction has been shown to be markedly attenuated and the LF component of systolic arterial pressure variability to be decreased after ACE inhibition, suggesting that the sympathetic vasomotor tone is blunted after RAS blockade.

In conclusion, cardiac autonomic regulation is not altered by chronic preoperative treatment with ACEIs and anesthetic-induced hypotension is mainly attributed to decreased -adrenergic vasoconstrictive response.

\section{References}

1 Garg R, Yusuf S. Overview of randomized trials of angiotensin-converting enzyme inhibitors on mortality and morbidity in patienst with heart failure. JAMA 1995; 273: 1450-6.

2 The Sixth Report of the Joint National Committee on prevention, detection, evaluation and treatment of high blood pressure. Arch Int Med 1997; 157: 2413-6.

3 Johnson DB, Foster RE, Barilla F, et al. ACE inhibitor therapy affects left ventricular mass in patients with ejection fraction $>40 \%$ after acute myocardial infarction. J Am Coll Cardiol 1997; 29: 49-54.

4 Coriat P, Richer C, Douraki T, et al. Influence of chronic angiotensin-converting enzyme inhibition on anesthetic induction. Anesthesiology 1994; 81: 299-307.

5 Tuman KJ, McCarthy RJ, O'Connor CJ, Holm WE, Ivankovitch $A D$ Angiotensin-converting enzyme inhibitors increase vasoconstrictor requirements after cardiopulmonary bypass. Anesth Analg 1995; 80: 473-9.

6 Licker M, Neidhart P, Lustenberger S, et al. Long term angiotensin-converting enzyme inhibition attenuates adrenergic responsiveness without altering hemodynamic control in patients undergoing cardiac surgery. Anesthesiology 1996; 84: 789-800.

7 Fariello R, Alicandri C, Boni E, et al. ACE inhibition, parasympathetic activity and exercise in essential hypertension. Drugs Exp Clin Res 1989; 15: 571-6.
8 Parati G, Saul JP, Di Rienzo M, Mancia GSpectral analysis of blood pressure and heart rate variability in evaluating cardiovascular regulation. A critical appraisal. Hypertension 1995; 25: 1276-86.

9 Akselrod S, Gordon D, Ubel F, Shannon D, Barger A, Cohen $R$. Power spectrum analysis of heart rate fluctuation: a quantitative probe of beat to beat cardiovascular control. Science 1981; 213: 220-2.

10 Pagani M, Lombardi F, Guzzetti S, et al. Power spectral analysis of heart rate and arterial pressure variabilities as a marker of sympatho-vagal interaction in man and conscious dog. Circ Res 1986; 59: 178-93.

11 Lord SW, Clayton RH, Hall MCS, et al. Reproductibility of three different methods of measuring baroreflex sensitivity in normal subjects. Clin Sci 1998; 95: 575-81.

12 Licker M, Farinelli C, Klopfenstein CE. Cardiovascular reflexes during anesthesia induction and tracheal intubation in elderly patients: the influence of thoracic epidural anesthesia. J Clin Anesth 1995; 7: 281-7.

13 Kankenas J. Concerning the estimation of order and parameters of the autoregression model. In: Statistical Problems of Management. Vylnius, Lituania: Institute of Mathematics and Cybernetics, University of Vylnius, 1983; 63: 46-61.

14 Myers MG Beta.adrenoceptor antagonism and pressor response to phenylephrine. Clin Pharmacol Ther 1984; 26: 57-63.

15 Grum DF, Azmy SS. Does propranolol alter the vascular response to phenylephrine before or during halothane anaesthesia in patients with coronary artery disease? Can J Anaesth 1992; 39: 41-6.

16 Magnusson J, Thulin T, Werner O, Jarhult J, Thompson $D$. Haemodynamic effects of pretreatment with metoprolol in hypertensive patients undergoing surgery. $\mathrm{Br}$ J Anaesth 1986; 58: 251-60.

17 Sanderson JE, Yeung LY, Yeung DT, et al. Impact of changes in respiratory frequency and posture on power spectral analysis of heart rate and systolic blood pressure variability in normal subjects and patients with heart failure. Clin Sci 1996; 91: 35-43.

18 La Rovere MT, Bigger JT Jr, Marcus FI, Mortara A, Schwartz PJ. Baroreflex sensitivity and heart-rate variability in prediction of total cardiac mortality after myocardial infarction. Lancet 1998; 351: 478-84.

19 Salo TM, Viikari JSA, Antila KJ, Voipio-Pulkki L-M, Jalonen JO, Välimäki IAT. Antihypertensive treatment and heart rate variability in diabetic patients: role of cardiac autonomic neuropathy. J Auton Nerv Syst 1996; 60: 61-70.

20 Van Boven AJ, Jukema JW, Crijns HJ, Lie KI. Heart rate variability profiles in symptomatic coronary artery disease and preserved left ventricular function: relation 
to ventricular tachycardia and transient myocardial ischemia. Am Heart J 1995; 130: 1020-5.

21 Francis GS, Cohn JN, Johnson G, Rector TS, Goldman S, Simon A Plasma norepinephrine, plasma renin activity, and congestive heart failure. Relations to survival and the effects of therapy in V-HeFT II. Circulation 1993; 87: VI40-8.

22 Grassi G, Cattaneo BM, Seravalle G, et al. Effects of chronic ACE inhibition on sympathetic nerve traffic and baroreflex control of circulation in heart failure. Circulation 1997; 96: 1173-9.

23 Goldstein DS. Arterial baroreflex sensitivity, plasma catecholamines and pressor responsiveness in essential hypertension. Circulation 1983; 68: 234-40.

24 Hirsch AT, Dzau VJ, Creager MA Baroreceptor function in congestive heart failure : effect on neurohumoral activation and regional vascular resistance. Circulation 1987; 75: IV4-36.

25 Kontopoulos AG, Athyros VG, Papageorgiou AA, Papadopoulos GV, Avramidis MJ, Boudoulas $H$. Effect of quinapril or metoprolol on heart rate variability in post-myocardial infarction patients. Am J Cardiol 1996; 77: 242-6.

26 Niemela MJ, Airaksinen KE, Huikuri HV. Effect of beta-blockade on heart rate variability in patients with coronary artery disease. J Am Coll Cardiol 1994; 23: 1370-7.

27 Latson TW, McCarroll SM, Mirhej MA, Hyndman VA, Whitten CW, Lipton JM Effects of three anesthetic induction techniques on heart rate variability. J Clin Anesth 1992; 4: 265-76.

28 Komatsu T, Kimura T, Sanchala V, Shibutani K, Shimada $\Upsilon$ Effects of fentanyl-diazepam-pancuronium anesthesia on heart rate variability: a spectral analysis. J Cardiothorac Vasc Anesth 1992; 6: 444-8.

29 Galletly DC, Corfiatis T, Westenberg AM, Robinson BJ. Heart rate periodicities during induction of propofol nitrous oxide-isoflurane anaesthesia. Br J Anaesth 1992; 68: 360-4.

30 Kotrly KJ, Ebert TJ, Vucins EJ, Roerig DL, Stadnicka A, Kampine JP. Effects of fentanyl-diazepam-nitrous oxide anaesthesia on arterial baroreflex control of heart rate in man. Br J Anaesth 1986; 58: 406-14.

31 Morioka S, Simon G, Cohn JN. Cardiac and hormonal effects of enalapril in hypertension. Clin Pharmacol Ther 1988; 34: 583-91.

32 Sear JW, Jewkes C, Tellez J-C, Foëx P. Does the choice of antihypertensive therapy influence haemodynamic responses to induction, laryngoscopy and intubation? Br J Anaesth 1994; 73: 303 ë8.

33 Schwinn DA, McIntyre $R W$, Hawkins ED, Kates $R A$, Reves $J G \alpha_{1}$-adrenergic responsiveness during coronary artery bypass surgery: effects of preoperative ejection fraction. Anesthesiology 1988; 69: 206-17.

34 Pagani M, Pizzinelli P, Mariani P, Lucini D, di Michele $R$, Malliani $A$. Effects of chronic cilazapril treatment on cardiovascular control: a spectral analytical approach. J Cardiovasc Pharmacol 1992; 19: S110-S116.

35 Grichois $M-L$, Blanc J, Deckert V, Elghozi J-L. Differential effects of enalapril and hydralazine on short-term variability of blood pressure and heart rate in rats. J Cardiovasc Pharmacol 1992; 19: 863-9.

36 Perondi R, Saino A, Tio RA, et al. ACE inhibition attenuates sympathetic coronary vasoconstriction in patients with coronary artery disease. Circulation 1992; 85: 2004-13. 